\title{
Synthesis of toxyloxanthone B
}

\author{
Daniele Giallombardo ${ }^{\mathrm{a}, \mathrm{b}}$, Adam C. Nevin ${ }^{\mathrm{a}}$, William Lewis ${ }^{\mathrm{a}}$, Christopher C. Nawrat ${ }^{\mathrm{a}}$, \\ Russell R.A. Kitson ${ }^{a}$, Christopher J. Moody ${ }^{\mathrm{a}, *}$ \\ ${ }^{a}$ School of Chemistry, University of Nottingham, University Park, Nottingham NG7 2RD, UK \\ ${ }^{\mathrm{b}}$ Dipartimento di Scienze e Tecnologie Biologiche Chimiche e Farmaceutiche (STEBICEF), Sezione di chimica farmaceutica e biologica, Via Archirafi 32, \\ 90123 Palermo, Italy
}

\section{A R T I C L E I N F O}

\section{Article history:}

Received 27 October 2013

Received in revised form 4 December 2013

Accepted 20 December 2013

Available online 8 January 2014

\section{Keywords:}

Natural products

Xanthones

Oxygen heterocycle

Benzyne addition

Claisen rearrangement

\begin{abstract}
A B S T R A C T
A synthesis of the naturally occurring xanthone toxyloxanthone B is described, in which the key step is the regioselective addition of a methyl salicylate to a substituted benzyne, followed by cyclization of the intermediate aryl anion to form the xanthone, the regiochemistry of the aryne addition being confirmed by X-ray crystallography. Subsequent introduction of the pyran ring by [3,3]-rearrangement and deprotection completed the synthesis.
\end{abstract}

() 2014 Elsevier Ltd. All rights reserved.

\section{Introduction}

Xanthones are widely distributed in Nature, occurring in a wide range of organisms from bacteria to higher plants. ${ }^{1}$ Not only are xanthones highly colored (Greek xanthos=yellow), they are also endowed with significant biological activity. Plants and trees of the Garcinia genus are a particularly rich source of bioactive xanthones, and recently isolated examples possess activity against platelet aggregation, ${ }^{2} \alpha$-glucosidases, ${ }^{3}$ cancer, $^{4}$ and MRSA. ${ }^{5,6}$ In higher plants, xanthones are of mixed polyketide and shikimic acid biosynthetic origin, with many examples also possessing isoprene- derived side chains. ${ }^{3-5}$ Indeed it was prenylated xanthones such as $\alpha$-mangostin $\mathbf{1}$, rubraxanthone $\mathbf{2}$, and toxyloxanthone B 3a (Fig. 1 ) that attracted our attention. $\alpha$-Mangostin 1, from Garcinia mangostana, is a potent inhibitor of sphingomyelinase, 7,8 whereas rubraxanthone 2, isolated from various members of the Garcinia genus, ${ }^{9,10}$ has a range of biological properties. ${ }^{11,12}$ The cytotoxic xanthone toxyloxanthone B 3a on the other hand is not Garciniaderived being originally isolated from Maclura pomifera and Toxylon pomiferum, ${ }^{13-16}$ and subsequently from the Hypericum genus, including Hypericum perforatum (St John's Wort). ${ }^{17,18}$ Surprisingly, despite their relative structural simplicity, $\alpha$-mangostin $\mathbf{1}$ is the only<smiles>COc1c(O)cc2oc3cc(O)c(CC=C(C)C)c(O)c3c(=O)c2c1CC=C(C)C</smiles><smiles>COc1c(O)cc2oc3cc(O)cc(O)c3c(=O)c2c1C/C=C(\C)CCC=C(C)C</smiles>

rubraxanthone 2<smiles>[R6]c1cc(O)c2c(=O)c3c4c(cc(O)c3oc2c1)OC(C)(C)C=C4</smiles>

$\mathrm{R}=\mathrm{H}$ toxyloxanthone $\mathrm{B} \mathbf{3 a}$ $\mathrm{R}=\mathrm{Me} \mathbf{3 b}$

Fig. 1. Some naturally occurring prenylated xanthones.

\footnotetext{
* Corresponding author. Fax: +44 115951 3564; e-mail address: c.j.moody@ nottingham.ac.uk (C.J. Moody).
}

one of the three compounds to be synthesized. ${ }^{8}$ We now report the synthesis of toxyloxanthone $\mathbf{3}$ that not only constitutes the first synthesis of the natural material, but also, as far as we are aware, 
illustrates the first use of the aryne-based methodology developed by Larock ${ }^{19,20}$ in the synthesis of bioactive natural products.

\section{Results and discussion}

The toxyloxanthones were first isolated from $M$. pomifera, ${ }^{13}$ although the originally assigned structure of toxyloxanthone B was corrected some two years later. Specifically, the position of the two methyl groups at C-3 was confirmed by NMR spectroscopy, ${ }^{14}$ and subsequently confirmed by an unambiguous synthesis of the trimethyl ether $\mathbf{3 b},{ }^{15,16}$ although the natural product itself has not been synthesized. In common with many other routes to xanthones, the synthesis of toxyloxanthone B trimethyl ether $\mathbf{3 b}$ was achieved in a classical sense by way of a suitably substituted benzophenone, ${ }^{16}$ but we were attracted by the more contemporary aryne-based method introduced by Larock. ${ }^{19,20}$ There has been a recent resurgence in interest in aryne chemistry, and their application in natural product synthesis is extremely topical. ${ }^{21-23}$ The Larock method involves the nucleophilic addition of the hydroxy group of a methyl salicylate to a benzyne followed by cyclization of the resulting aryl anion onto the methyl ester (Scheme 1). In the case of toxyloxanthone B 3a, the required coupling partners would be the methyl salicylate $\mathbf{4}$ and the ortho-trimethylsilyl triflate aryne precursor $\mathbf{5}$, with benzyl protecting groups chosen for the three phenolic hydroxy groups, with the remaining phenol in $\mathbf{4}$ orthogonally protected as its MOM-ether. The substituted benzyne derived from precursor $\mathbf{5}$ is unsymmetrical and therefore could lead to two nucleophilic addition products. However, Stoltz and coworkers have previously shown that the aryne derived from $\mathbf{5}$ undergoes regioselective attack as indicated in Scheme $1,{ }^{24}$ and therefore we were confident that the correct xanthone would result from our projected coupling reaction.

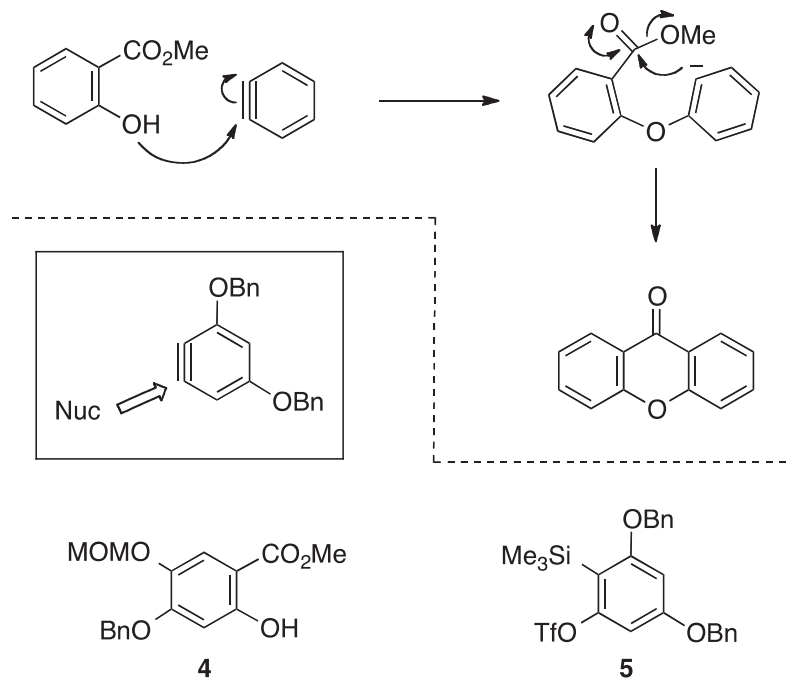

Scheme 1. Larock benzyne-based route to xanthones, and the proposed precursors to toxyloxanthone $\mathrm{B}$.

The methyl salicylate 4 was obtained from methyl 2,4hydroxybenzoate $\mathbf{6}$ by selective protection of the non-hydrogen bonded phenol to give salicylate 7. Subsequent Elbs persulfate oxidation ${ }^{25}$ gave the hydroquinone 8 albeit in poor yield, although the $64 \%$ recovery of starting material 7 rendered the process viable. Selective protection of the non-hydrogen bonded phenol as its MOM-ether gave the required methyl salicylate $\mathbf{4}$ (Scheme 2). The aryne precursor $\mathbf{5}$ was prepared from phloroglucinol as described by Stoltz and co-workers, ${ }^{24}$ setting the stage for the key step. Generation of the aryne from the triflate $\mathbf{5}$ with cesium fluoride in
THF in the presence of the methyl salicylate $\mathbf{4}$ as described by Larock and co-workers gave the desired xanthone 9, but in 1:1 admixture with the ortho-aryloxy benzoate $\mathbf{1 0}$ (Scheme 2). Reasoning that the only source of protonation of the intermediate aryl anion was the salicylate $\mathbf{4}$ itself, a change in conditions involving the addition of sodium hydride for prior deprotonation of the phenol resulted in an improved yield (40\%) of the desired xanthone $\mathbf{9}$, although the benzoate $\mathbf{1 0}$ was still formed (30\%). As expected, the nucleophilic addition to the unsymmetrical benzyne derived from triflate $\mathbf{5}$ was highly regioselective resulting in the formation of the 1,3,6-tribenzyloxyxanthone 9. The alternative regioisomer, the 2,4,6-tribenzyloxyxanthone, that would result from attack on the other aryne carbon was not observed. In terms of obtaining quantities of xanthone $\mathbf{9}$, the formation of benzoate $\mathbf{1 0}$ was inconsequential since ester hydrolysis and cyclization onto the electron rich aromatic ring in the presence of trifluoroacetic acid anhydride provided further material.

With the xanthone $\mathbf{9}$ available in quantity, the MOM-ether was cleaved under acidic conditions, and the resulting phenol $\mathbf{1 1}$ was

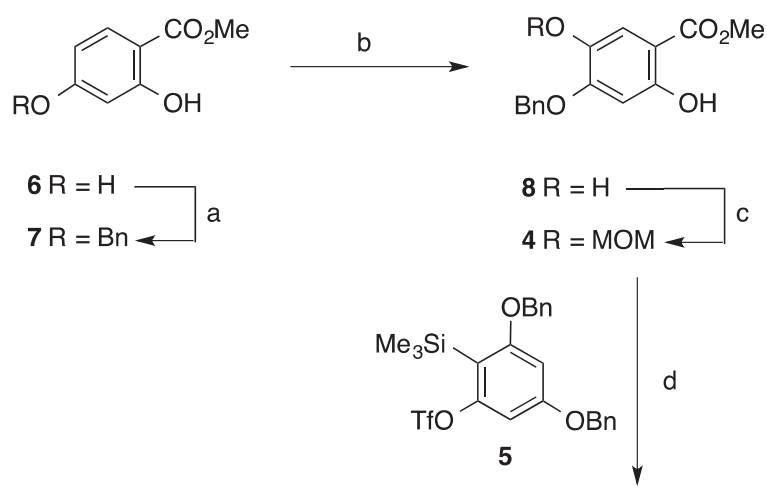<smiles>COC(=O)c1cc(OCc2ccccc2)c(OC)cc1Oc1cc(OCc2ccccc2)cc(Oc2cc(OCc3ccccc3)c(OC)cc2OCc2ccccc2)c1</smiles><smiles>C#CC(C)(C)Oc1cc2c(=O)c3c(OCc4ccccc4)cc(OCc4ccccc4)cc3oc2cc1OCc1ccccc1</smiles>

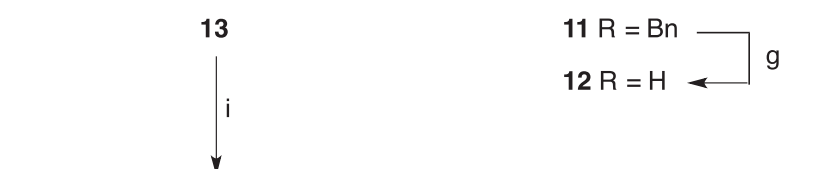<smiles>CC1(C)C=Cc2c(c(OCc3ccccc3)cc3oc4cc(OCc5ccccc5)cc(OCc5ccccc5)c4c(=O)c23)O1</smiles>

Scheme 2. Reagents and conditions: (a) $\mathrm{BnBr}, \mathrm{K}_{2} \mathrm{CO}_{3}$, acetone, rt (82\%); (b) $\mathrm{K}_{2} \mathrm{~S}_{2} \mathrm{O}_{8}$ $\mathrm{NaOH}$, water, rt (15\%+64\% recovered 7); (c) $\mathrm{MOMCl}, i-\mathrm{Pr}_{2} \mathrm{NEt}, \mathrm{CH}_{2} \mathrm{Cl}_{2}$, rt (70\%); (d) $\mathrm{NaH}$ CsF, THF, $65{ }^{\circ} \mathrm{C}\left(40 \%+30 \%\right.$ 10); (e) LiOH, MeOH, aq THF, then TFAA, $\mathrm{CH}_{2} \mathrm{Cl}_{2}$, rt (99\%); (f) TFA, $\mathrm{CH}_{2} \mathrm{Cl}_{2}$, rt (94\%); (g) $\mathrm{MgBr}_{2}$, toluene, reflux (10\%); (h) $\mathrm{HCCCMe} 2 \mathrm{Cl}, \mathrm{KI}_{2} \mathrm{~K}_{2} \mathrm{CO}_{3}$, acetone, reflux (75\%); (i) toluene, reflux (100\%); (j) $\mathrm{BCl}_{3}$ (1 $\mathrm{M}$ in hexane), pentamethylbenzene, $\mathrm{CH}_{2} \mathrm{Cl}_{2},-78{ }^{\circ} \mathrm{C}$, then rt (64\%). 
further deprotected by selective removal of the benzyl group perito the carbonyl by treatment with magnesium bromide in boiling toluene. The structure of the resulting phenol 12 was confirmed by X-ray crystallography (Fig. 2), providing unambiguous evidence for the regiochemistry of the aryne addition. Alkylation of phenol $\mathbf{1 1}$ with 3-chloro-3-methylbutyne gave the propargyl ether 13 in good yield. Claisen rearrangement under mild conditions ${ }^{26}$ resulted in formation of the fused pyran ring to give protected toxyloxanthone 14 in quantitative yield (Scheme 2). The final step required the removal of three benzyl protecting groups, and although this could not be carried out under catalytic transfer hydrogenation with ammonium formate as hydrogen donor, ${ }^{27}$ treatment with boron trichloride in dichloromethane in the presence of pentamethylbenzene ${ }^{28}$ at $-78{ }^{\circ} \mathrm{C}$ initially removed two of the benzyl groups. For full deprotection, the reaction mixture required warming to room temperature with extra boron trichloride, which pleasingly gave the xanthone 3a (toxyloxanthone) in 64\% yield.

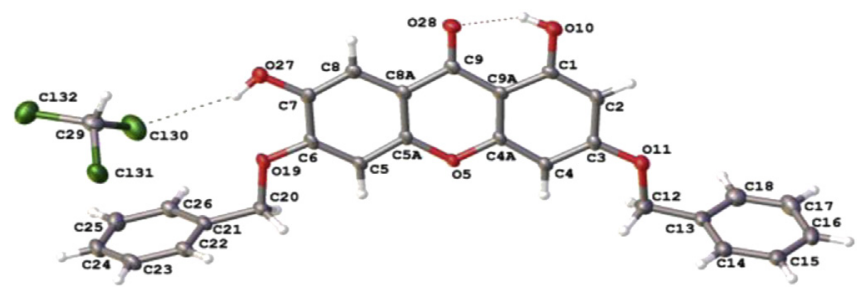

Fig. 2. X-ray crystal structure of 3,6-dibenzyloxy-1,7-dihydroxy-9H-xanthen-9-one 12 (with one molecule of chloroform) CCDC number 973933.

The ${ }^{1} \mathrm{H}$ spectroscopic properties of the synthetic material closely matched those described for the natural product, ${ }^{17,18}$ although the ${ }^{13} \mathrm{C}$ NMR gave a systematic difference in the chemical shifts of $0.8-1.1 \mathrm{ppm}$. We assumed that this was due to incorrect calibration of the original spectrum, and indeed when we re-referenced the residual acetone peak, a near perfect match to the reported literature values was observed. Additionally, for further comparison, toxyloxanthone B 3a was converted into the known trimethyl ether 3b by reaction with dimethyl sulfate, the ${ }^{1} \mathrm{H}$ NMR spectroscopic data of which were identical with those reported. ${ }^{16}$ The first synthesis of the naturally occurring xanthone toxyloxanthone B further demonstrates the use of arynes in synthesis, and in particular that the Larock xanthone methodology can be successfully applied in the synthesis of relatively complex natural products.

\section{Experimental section}

\subsection{General information}

Commercially available reagents were used throughout without purification unless otherwise stated. All anhydrous solvents were used as supplied, except tetrahydrofuran and dichloromethane that were freshly distilled according to standard procedures. Reactions were routinely carried out under an argon atmosphere unless otherwise stated, and all glassware was flame-dried before use. Light petroleum refers to the fraction with bp $40-60{ }^{\circ} \mathrm{C}$. Ether refers to diethyl ether.

Analytical thin layer chromatography was carried out on aluminum backed plates coated with silica gel, and visualized under UV light at 254 and/or $360 \mathrm{~nm}$ and/or by chemical staining. Flash chromatography was carried out using silica gel, with the eluant specified.

Infrared spectra were recorded using an FT-IR spectrometer over the range $4000-600 \mathrm{~cm}^{-1}$. NMR spectra were recorded at 400 or $500 \mathrm{MHz}\left({ }^{1} \mathrm{H}\right.$ frequency, 100 or $125 \mathrm{MHz}{ }^{13} \mathrm{C}$ frequency). Chemical shifts are quoted in parts per million ( $\mathrm{ppm}$ ), and are referenced to residual $\mathrm{H}$ in the deuterated solvent as the internal standard. Coupling constants, $J$, are quoted in hertz $(\mathrm{Hz})$. In the ${ }^{13} \mathrm{C}$ NMR spectra, signals corresponding to $\mathrm{CH}, \mathrm{CH}_{2}$, or $\mathrm{CH}_{3}$ groups are assigned from DEPT. Mass spectra were recorded on a time-of-flight mass spectrometer using electrospray ionization (ESI), or an EI magnetic sector instrument.

\subsection{3,5-Dibenzyloxy-2-trimethylsilylphenyl trifluoromethane sulfonate 5}<smiles>CCCCc1cc(OCc2ccccc2)cc(OCC)c1[SiH3]</smiles>

The title compound was prepared by the method of Stoltz and co-workers. $^{24}$

\subsection{Methyl 4-benzyloxy-2-hydroxybenzoate 7}<smiles>CC(=O)c1ccc(OCc2ccccc2)cc1O</smiles>

A mixture of methyl 2,4-dihydroxybenzoate 6 (4.00 g, $23.8 \mathrm{mmol})$ and anhydrous potassium carbonate $(4.90 \mathrm{~g}$, $35.7 \mathrm{mmol})$ in acetone $(22 \mathrm{~mL})$ was stirred at room temperature for $5 \mathrm{~min}$. Benzyl bromide ( $2.83 \mathrm{~mL}, 23.8 \mathrm{mmol}$ ) was added dropwise and the mixture was stirred at $10-15^{\circ} \mathrm{C}$ for $3 \mathrm{~h}$. Water $(30 \mathrm{~mL})$ and ethyl acetate $(30 \mathrm{~mL})$ were added and the two phases were separated. The aqueous phase was extracted with further ethyl acetate $(3 \times 40 \mathrm{~mL})$. The combined organic layers were washed with brine $\left(40 \mathrm{~mL}\right.$ ), dried over $\mathrm{MgSO}_{4}$, filtered, and concentrated under reduced pressure. The residue was purified by flash column chromatography (9:1 light petroleum/ethyl acetate) to give the title compound $(5.06 \mathrm{~g}, 82 \%)$ as a colorless solid, $\mathrm{mp} 103-105{ }^{\circ} \mathrm{C}$ (lit., ${ }^{29}$ mp 103-105 ${ }^{\circ} \mathrm{C}$ ). Found: $\left[\mathrm{M}+\mathrm{Na}^{+}\right]$, 281.0781. $\mathrm{C}_{15} \mathrm{H}_{14} \mathrm{NaO}_{4}{ }^{+}$requires 281.0784; $\nu_{\max }\left(\mathrm{CHCl}_{3}\right) / \mathrm{cm}^{-1} 3008,2956,1668,1623,1583$, $1505,1441,1382,1349,1255,1183,1142,1099,1014 ; \delta_{\mathrm{H}}(400 \mathrm{MHz}$; DMSO-d6) $10.78(1 \mathrm{H}, \mathrm{s}), 7.74(1 \mathrm{H}, \mathrm{d}, J 7.2), 7.47-7.36(5 \mathrm{H}, \mathrm{m})$, $6.64-6.61(2 \mathrm{H}, \mathrm{m}), 5.18(2 \mathrm{H}, \mathrm{s}), 3.88(3 \mathrm{H}, \mathrm{s}) ; \delta_{\mathrm{C}}\left(100 \mathrm{MHz}\right.$; DMSO-d $\left.d_{6}\right)$ $169.8(\mathrm{C}), 164.7(\mathrm{C}), 163.0(\mathrm{C}), 136.8(\mathrm{C}), 131.8(\mathrm{CH}), 128.9(\mathrm{CH}), 128.5$ $(\mathrm{CH}), 128.2(\mathrm{CH}), 108.5(\mathrm{CH}), 105.9(\mathrm{C}), 102.4(\mathrm{CH}), 70.1\left(\mathrm{CH}_{2}\right), 52.7$ (Me).

\subsection{Methyl 4-benzyloxy-2,5-dihydroxybenzoate 8}<smiles>CC(=O)c1cc(O)c(OCc2ccccc2)cc1O</smiles>

To a stirred mixture of methyl 4-benzyloxy-2-hydroxybenzoate $7(3.50 \mathrm{~g}, 13.5 \mathrm{mmol})$ in an aqueous solution of $\mathrm{NaOH}(1 \mathrm{M} ; 135 \mathrm{~mL})$ at $0{ }^{\circ} \mathrm{C}$ was added over $30 \mathrm{~min}$, a solution of potassium persulfate $(7.70 \mathrm{~g}, 28.5 \mathrm{mmol})$ in water $(135 \mathrm{~mL})$. After stirring for $20 \mathrm{~h}$ at room temperature, the reaction mixture was acidified to $\mathrm{pH} 4$ with concentrated hydrochloric acid. The mixture was filtered to remove the unreacted starting material $(2.25 \mathrm{~g}, 64 \%$ recovery). Further concentrated hydrochloric acid $(30 \mathrm{~mL})$ was added to the aqueous phase and the mixture heated to $80^{\circ} \mathrm{C}$ for $2 \mathrm{~h}$. After cooling to room temperature, ethyl acetate $(150 \mathrm{~mL})$ was added, and then the aqueous layer was extracted with further ethyl acetate $(3 \times 200 \mathrm{~mL})$. The combined organic phases were dried over $\mathrm{MgSO}_{4}$ and 
evaporated to give a dark oil that was purified by column chromatography (9:1 light petroleum/ethyl acetate). The product was crystallized from methanol to give the title compound as a colorless solid (560 mg, 15\%), mp $165-167{ }^{\circ} \mathrm{C}$. Found: $\left[\mathrm{M}+\mathrm{Na}^{+}\right], 297.0716$. $\mathrm{C}_{15} \mathrm{H}_{14} \mathrm{NaO}_{5}{ }^{+}$requires 297.0733; $\nu_{\max }\left(\mathrm{CHCl}_{3}\right) / \mathrm{cm}^{-1} 3684,3555$, 3011, 2956, 1669, 1635, 1509, 1440, 1399, 1374, 1276, 1239, 1168, 1082,$1000 ; \delta_{\mathrm{H}}\left(400 \mathrm{MHz}\right.$; DMSO- $\left.d_{6}\right) 10.33(1 \mathrm{H}, \mathrm{s}), 8.94(1 \mathrm{H}, \mathrm{s})$, 7.50-7.35 (5H, m), $7.18(1 \mathrm{H}, \mathrm{s}), 6.63(1 \mathrm{H}, \mathrm{s}), 5.18(2 \mathrm{H}, \mathrm{s}), 3.86(3 \mathrm{H}, \mathrm{s})$; $\delta_{\mathrm{C}}\left(100 \mathrm{MHz}\right.$; DMSO- $\left.d_{6}\right) 170.0$ (C), 156.1 (C), 154.2 (C), 140.1 (C), $136.9(\mathrm{C}), 128.9(\mathrm{CH}), 128.4(\mathrm{CH}), 128.2(\mathrm{CH}), 114.4(\mathrm{CH}), 103.7(\mathrm{C})$, $102.1(\mathrm{CH}), 70.2\left(\mathrm{CH}_{2}\right), 52.6(\mathrm{Me})$.

\subsection{Methyl 4-benzyloxy-2-hydroxy-5-methoxymethoxybenzo ate 4}<smiles>COc1cc(OCc2ccccc2)c(O)cc1C(C)=O</smiles>

To a solution of methyl 4-benzyloxy-2,5-dihydroxybenzoate 8 (450 mg, $1.64 \mathrm{mmol}$ ) in dichloromethane $(18 \mathrm{~mL})$ at $0{ }^{\circ} \mathrm{C}$, was added DIPEA (0.51 mL, $2.95 \mathrm{mmol})$, and after a few minutes, MOMCl $(0.14 \mathrm{~mL}, 1.8 \mathrm{mmol})$. The mixture was stirred for $2 \mathrm{~h}$ at room temperature. Water $(15 \mathrm{~mL})$ was added and the mixture was extracted with ethyl acetate $(3 \times 15 \mathrm{~mL})$. The combined organic extract was dried over $\mathrm{MgSO}_{4}$, and evaporated. The residue was purified by flash column chromatography (9:1 light petroleum/ethyl acetate) to give the title compound as a colorless solid ( $410 \mathrm{mg}, 70 \%), \mathrm{mp}$ 103-105 ${ }^{\circ} \mathrm{C}$. Found: $\left[\mathrm{M}+\mathrm{Na}^{+}\right]$, 341.0994. $\mathrm{C}_{17} \mathrm{H}_{18} \mathrm{NaO}_{6}{ }^{+}$requires 341.0996; $\nu_{\max }\left(\mathrm{CHCl}_{3}\right) / \mathrm{cm}^{-1} 3154,3011,2955,1668,1620,1511$, 1497, 1441, 1355, 1259, 1192, 1162, 1097, 1070, 988; $\delta_{\mathrm{H}}(400 \mathrm{MHz}$; DMSO- $\left.d_{6}\right) 10.58(1 \mathrm{H}, \mathrm{s}), 7.48-7.37(6 \mathrm{H}, \mathrm{m}), 6.73(1 \mathrm{H}, \mathrm{s}), 5.20(2 \mathrm{H}, \mathrm{s})$, $5.09(2 \mathrm{H}, \mathrm{s}), 3.88(3 \mathrm{H}, \mathrm{s}), 3.39(3 \mathrm{H}, \mathrm{s}) ; \delta_{\mathrm{C}}\left(100 \mathrm{MHz}\right.$; DMSO- $\left.d_{6}\right) 169.7$ (C), $158.4(\mathrm{C}), 156.3(\mathrm{C}), 139.5(\mathrm{C}), 136.6(\mathrm{C}), 129.0(\mathrm{CH}), 128.6(\mathrm{CH})$, $128.3(\mathrm{CH}), 117.8(\mathrm{CH}), 103.9(\mathrm{C}), 102.4(\mathrm{CH}), 96.2\left(\mathrm{CH}_{2}\right), 70.5\left(\mathrm{CH}_{2}\right)$, $56.2(\mathrm{Me}), 52.7(\mathrm{Me})$.

\subsection{1,3,6-Tribenzyloxy-7-methoxymethoxy-9H-xanthen-9- one 9}<smiles>COc1cc2c(=O)c3c(OCc4ccccc4)cc(Cc4ccccc4)cc3oc2cc1OCc1ccccc1</smiles>

To a solution of methyl 4-benzyloxy-2-hydroxy-5methoxymethoxybenzoate 4 (409 $\mathrm{mg}, 1.28 \mathrm{mmol}$ ) in THF $(15 \mathrm{~mL})$ at room temperature was added sodium hydride ([60\% dispersion in mineral oil] $52 \mathrm{mg}, 1.29 \mathrm{mmol}$ ) and the mixture was left to stir for $45 \mathrm{~min}$. The mixture was heated to $65^{\circ} \mathrm{C}$ and cesium fluoride ( $780 \mathrm{mg}, 5.14 \mathrm{mmol}$ ) was added, followed by a solution of 3,5-dibenzyloxy-2-trimethylsilylphenyl trifluoromethanesulfonate 5 ( $720 \mathrm{mg}, 1.41 \mathrm{mmol})$ in THF $(10 \mathrm{~mL})$, over $30 \mathrm{~min}$. The mixture was stirred for $24 \mathrm{~h}$ at $65{ }^{\circ} \mathrm{C}$, then cooled, diluted with ether $(100 \mathrm{~mL})$, and washed with brine $(100 \mathrm{~mL})$. The aqueous layer was extracted with ethyl acetate $(2 \times 60 \mathrm{~mL})$, the combined organic extracts dried over $\mathrm{MgSO}_{4}$, filtered, and evaporated. The residue was purified by flash column chromatography (8:2 light petroleum/ethyl acetate) to give the title compound as a light brown solid ( $295 \mathrm{mg}, 40 \%$ ), mp 148-150 ${ }^{\circ} \mathrm{C}$. Found: $\left[\mathrm{M}+\mathrm{H}^{+}\right]$, 575.2062. $\mathrm{C}_{36} \mathrm{H}_{31} \mathrm{O}_{7}{ }^{+}$requires 575.2064; $\nu_{\max }\left(\mathrm{CHCl}_{3}\right) / \mathrm{cm}^{-1} 3068,3010,2931,1715,1644,1624$, $1606,1499,1453,1438,1376,1268,1182,1156,1122,1076 ; \delta_{\mathrm{H}}$ $\left(400 \mathrm{MHz} ; \mathrm{CDCl}_{3}\right) 8.00(1 \mathrm{H}, \mathrm{s}), 7.67(2 \mathrm{H}, \mathrm{d}, J 7.1), 7.51-7.34(13 \mathrm{H}, \mathrm{m})$, $6.87(1 \mathrm{H}, \mathrm{s}, \mathrm{H}-5), 6.55(1 \mathrm{H}, \mathrm{d}, J 2.3), 6.50(1 \mathrm{H}, \mathrm{d}, J 2.3), 5.31(2 \mathrm{H}, \mathrm{s})$,
$5.27(2 \mathrm{H}, \mathrm{s}), 5.25(2 \mathrm{H}, \mathrm{s}), 5.14(2 \mathrm{H}, \mathrm{s}), 3.56(3 \mathrm{H}, \mathrm{s}) ; \delta_{\mathrm{C}}(100 \mathrm{MHz}$; $\left.\mathrm{CDCl}_{3}\right) 174.3$ (C), 163.3 (C), 160.7 (C), 159.7 (C), 154.6 (C), 151.6 (C), 143.9 (C), $136.4(\mathrm{C}), 135.9(\mathrm{C}), 135.8(\mathrm{C}), 128.8(\mathrm{CH} \times 2), 128.6(\mathrm{CH})$, 128.4 $(\mathrm{CH}), 128.3(\mathrm{CH}), 127.7(\mathrm{CH}), 127.6(\mathrm{CH}), 127.2(\mathrm{CH}), 126.8(\mathrm{CH})$, 116.6 (C), 113.2 (CH), 107.5 (C), 101.0 (CH), 97.2 (CH), $96.1\left(\mathrm{CH}_{2}\right), 94.0$ $(\mathrm{CH}), 71.0\left(\mathrm{CH}_{2}\right), 70.8\left(\mathrm{CH}_{2}\right), 70.5\left(\mathrm{CH}_{2}\right), 56.4(\mathrm{Me})$.<smiles>COC(=O)c1cc(OC)c(OCc2ccccc2)cc1Oc1cc(OCc2ccccc2)cc(OCc2ccccc2)c1</smiles>

Also formed was methyl 4-benzyloxy-2-(3,5-dibenzyloxy)phenoxy-5-methoxymethoxybenzoate 10 (235 mg, 30\%), mp 70-71 ${ }^{\circ} \mathrm{C}$. Found: $\left[\mathrm{M}+\mathrm{Na}^{+}\right], 629.2125 . \mathrm{C}_{37} \mathrm{H}_{34} \mathrm{NaO}_{8}{ }^{+}$requires 629.2146; $\nu_{\max }$ $\left(\mathrm{CHCl}_{3}\right) / \mathrm{cm}^{-1} 3091,3068,3009,1715,1605,1509,1455,1265,1155$, $1129 ; \delta_{\mathrm{H}}\left(400 \mathrm{MHz} ; \mathrm{CDCl}_{3}\right) 7.73(1 \mathrm{H}, \mathrm{s}), 7.44-7.28(15 \mathrm{H}, \mathrm{m}), 6.60$ $(1 \mathrm{H}, \mathrm{s}), 6.35(1 \mathrm{H}, \mathrm{t}, J 2.1), 6.12(2 \mathrm{H}, \mathrm{d}, J 2.1), 5.24(2 \mathrm{H}, \mathrm{s}), 5.05(2 \mathrm{H}, \mathrm{s})$ $4.97(4 \mathrm{H}, \mathrm{s}), 3.75(3 \mathrm{H}, \mathrm{s}), 2.90(3 \mathrm{H}, \mathrm{s}) ; \delta_{\mathrm{C}}\left(100 \mathrm{MHz} ; \mathrm{CDCl}_{3}\right) 165.0(\mathrm{C})$, 160.7 (C), $160.3(\mathrm{C}), 153.6(\mathrm{C}), 151.5(\mathrm{C}), 143.1(\mathrm{C}), 136.7(\mathrm{C}), 135.8(\mathrm{C})$, $128.7(\mathrm{CH}), 128.6(\mathrm{CH}), 128.2(\mathrm{CH}), 128.1(\mathrm{CH}), 127.6(\mathrm{CH}), 127.4(\mathrm{CH})$, $120.1(\mathrm{CH}), 115.3(\mathrm{C}), 108.0(\mathrm{CH}), 96.9(\mathrm{CH}), 96.5(\mathrm{CH}), 96.1\left(\mathrm{CH}_{2}\right)$, $70.7\left(\mathrm{CH}_{2}\right), 70.1\left(\mathrm{CH}_{2}\right), 56.5(\mathrm{Me}), 52.0(\mathrm{Me})$.

\subsection{1,3,6-Tribenzyloxy-7-methoxymethoxy-9H-xanthen-9- one 9 (method 2$)$}

To a solution of methyl 4-benzyloxy-2-(3,5-dibenzyloxy)phenoxy-5-methoxymethoxybenzoate $10(500 \mathrm{mg}, 0.83 \mathrm{mmol})$ in methanol $(14 \mathrm{~mL})$ at $0{ }^{\circ} \mathrm{C}$ was added a solution of $\mathrm{LiOH}(395 \mathrm{mg}$, $16.5 \mathrm{mmol})$ in a mixture of THF/water $(1: 1,7 \mathrm{~mL})$, and the mixture was stirred at room temperature for $7 \mathrm{~h}$. The mixture was concentrated under reduced pressure, the residue diluted with water $(5 \mathrm{~mL})$ and acidified to $\mathrm{pH} 6$ with hydrochloric acid $(2 \mathrm{M})$, and then extracted with ethyl acetate $(3 \times 20 \mathrm{~mL})$. The combined organic extracts were dried with $\mathrm{MgSO}_{4}$ and concentrated under reduced pressure, to give the benzoic acid that was used immediately in the next step.

The above acid was taken up in dichloromethane $(9 \mathrm{~mL})$ and the solution cooled to $0{ }^{\circ} \mathrm{C}$. Trifluoroacetic anhydride $(0.69 \mathrm{~mL}$, $4.95 \mathrm{mmol}$ ) was added slowly and the mixture was stirred for $3 \mathrm{~h}$ at room temperature. After this period, the mixture was concentrated under reduced pressure and diluted with a saturated solution of sodium hydrogen carbonate $(10 \mathrm{~mL})$. The mixture was extracted with dichloromethane $(3 \times 15 \mathrm{~mL})$ and the combined organic fractions were dried over $\mathrm{MgSO}_{4}$ and concentrated under reduced pressure to give the title compound as a light brown solid (465 mg, $99 \%$ ) that did not require further purification.

\subsection{7-Hydroxy-1,3,6-tribenzyloxy-9H-xanthen-9-one 11}<smiles>O=c1c2ccc(OCc3ccccc3)cc2oc2cc(OCc3ccccc3)c(OCc3ccccc3)cc12</smiles>

To a solution of 1,3,6-tribenzyloxy-7-methoxymethoxy-9Hxanthen-9-one 9 (380 $\mathrm{mg}, 0.66 \mathrm{mmol}$ ) in anhydrous dichloromethane $(24 \mathrm{~mL})$ at $0{ }^{\circ} \mathrm{C}$ was added trifluoroacetic acid $(4 \mathrm{~mL})$, and the reaction mixture was stirred for $30 \mathrm{~min}$ at room temperature. Saturated aqueous sodium hydrogen carbonate $(30 \mathrm{~mL})$ was added slowly and the mixture extracted with ethyl acetate $(3 \times 30 \mathrm{~mL})$. The combined organic extracts were washed with saturated brine $(10 \mathrm{~mL})$, dried over $\mathrm{MgSO}_{4}$, filtered, and concentrated under reduced pressure. The residual oil was purified by flash column chromatography (7:3 light petroleum/ethyl acetate) to give the title 
compound as a colorless solid (330 mg, 94\%), $\mathrm{mp} 173-175^{\circ} \mathrm{C}$. Found: $\left[\mathrm{M}+\mathrm{H}^{+}\right]$, 531.1814. $\mathrm{C}_{34} \mathrm{H}_{27} \mathrm{O}_{6}{ }^{+}$requires 531.1802; $\nu_{\max }\left(\mathrm{CHCl}_{3}\right) / \mathrm{cm}^{-1}$ $3687,3603,3011,1630,1602,1500,1438,1272,1239,1174,1118,1017$; $\delta_{\mathrm{H}}\left(400 \mathrm{MHz} ; \mathrm{CDCl}_{3}\right) 7.82(1 \mathrm{H}, \mathrm{s}), 7.62(2 \mathrm{H}, \mathrm{d}, J 7.3), 7.48-7.35(13 \mathrm{H}$, $\mathrm{m}), 6.91(1 \mathrm{H}, \mathrm{s}), 6.54(1 \mathrm{H}, \mathrm{s}), 6.48(1 \mathrm{H}, \mathrm{s}), 5.27(2 \mathrm{H}, \mathrm{s}), 5.24(2 \mathrm{H}, \mathrm{s})$, $5.13(2 \mathrm{H}, \mathrm{s}) ; \delta_{\mathrm{C}}\left(100 \mathrm{MHz} ; \mathrm{CDCl}_{3}\right) 175.0(\mathrm{C}), 163.5(\mathrm{C}), 160.7$ (C), 159.8 (C), 151.2 (C), 150.2 (C), 143.0 (C), 136.3 (C), 135.7 (C), 135.0 (C), 129.0 $(\mathrm{CH}), 128.9(\mathrm{CH}), 128.8(\mathrm{CH}), 128.7(\mathrm{CH}), 128.4(\mathrm{CH}), 127.9(\mathrm{CH}), 127.8$ $(\mathrm{CH}), 127.6(\mathrm{CH}), 126.8(\mathrm{CH}), 117.0(\mathrm{C}), 109.9(\mathrm{CH}), 107.3(\mathrm{C}), 99.6(\mathrm{CH})$, $97.1(\mathrm{CH}), 94.0(\mathrm{CH}), 71.6\left(\mathrm{CH}_{2}\right), 70.8\left(\mathrm{CH}_{2}\right), 70.5\left(\mathrm{CH}_{2}\right)$.

\subsection{3,6-Dibenzyloxy-1,7-dihydroxy-9H-xanthen-9-one 12}<smiles>CC(C)Oc1cc(O)c2c(=O)c3cc(O)c(OCc4ccccc4)cc3oc2c1</smiles>

Anhydrous magnesium bromide (118 $\mathrm{mg}, 0.641 \mathrm{mmol}$ ) was added to 7-hydroxy-1,3,6-tribenzyloxy-9H-xanthen-9-one 11 (68 $\mathrm{mg}, 0.128 \mathrm{mmol}$ ) in toluene $(2 \mathrm{~mL}$ ) and the yellow suspension was heated to reflux and stirred for $15 \mathrm{~h}$, turning deep red. Hydrochloric acid $(5 \mathrm{~mL})$ was added, and the aqueous phase was extracted with ethyl acetate $(3 \times 10 \mathrm{~mL})$. The combined organic extracts were washed with water $(30 \mathrm{~mL})$ and brine $(30 \mathrm{~mL})$, dried $\left(\mathrm{MgSO}_{4}\right)$, and concentrated under reduced pressure. The residue was purified by flash column chromatography (2:3 ethyl acetate/light petroleum) to give the title compound as a pale yellow solid ( $5 \mathrm{mg}, 10 \%$ ); $\mathrm{mp}$ 173-174 ${ }^{\circ} \mathrm{C}$. Found: $\left[\mathrm{M}+\mathrm{Na}^{+}\right]$, 463.1149. $\mathrm{C}_{27} \mathrm{H}_{20} \mathrm{NaO}_{6}{ }^{+}$requires 463.1200; $\nu_{\max }\left(\mathrm{CHCl}_{3}\right) / \mathrm{cm}^{-1} 3632,3550,3071,3013,2947,2890$, 2852, 1654, 1614, 1488, 1289, 1174; $\delta_{\mathrm{H}}\left(400 \mathrm{MHz}\right.$; DMSO-d $\left.d_{6}\right) 13.07$ $(1 \mathrm{H}, \mathrm{s}), 9.87(1 \mathrm{H}, \mathrm{s}), 7.53-7.56(10 \mathrm{H}, \mathrm{m}), 7.23-7.21(2 \mathrm{H}, \mathrm{m}), 6.65(1 \mathrm{H}$, d, J 2.2), $6.46\left(1 \mathrm{H}, \mathrm{d}, J\right.$ 2.2), $5.31(2 \mathrm{H}, \mathrm{s}), 5.25(2 \mathrm{H}, \mathrm{s}) ; \delta_{\mathrm{C}}(100 \mathrm{MHz}$; DMSO- $\left.d_{6}\right) 179.6(\mathrm{C}), 165.2(\mathrm{C}), 162.8(\mathrm{C}), 157.6(\mathrm{C}), 154.7(\mathrm{C}), 151.2(\mathrm{C})$, 145.2 (C), 136.6 (C × 2), 129.0 (CH), 128.8 (CH), $128.7(\mathrm{CH}), 128.6(\mathrm{CH})$, $128.43(\mathrm{CH}), 128.40(\mathrm{CH}), 113.3(\mathrm{C}), 108.2(\mathrm{CH}), 103.2(\mathrm{C}), 101.8(\mathrm{CH})$, $97.9(\mathrm{CH}), 93.7(\mathrm{CH}), 70.8\left(\mathrm{CH}_{2}\right), 70.5\left(\mathrm{CH}_{2}\right)$.

3.10. 7-(2,2-Dimethylbut-3-ynyl)-1,3,6-tribenzyloxy-9Hxanthen-9-one 13<smiles>C#CC(C)(C)Oc1cc2c(=O)c3c(OCc4ccccc4)cc(Cc4ccccc4)cc3oc2cc1OCc1ccccc1</smiles>

Potassium carbonate ( $82 \mathrm{mg}, 0.594 \mathrm{mmol}$ ) and potassium iodide (82 $\mathrm{mg}, 0.49 \mathrm{mmol}$ ) were added to a solution of 7-hydroxy-1,3,6tribenzyloxy-9H-xanthen-9-one $11(150 \mathrm{mg}, 0.283 \mathrm{mmol})$ in acetone $(15 \mathrm{~mL}) .3-$ Chloro-3-methyl-1-butyne $(80 \mu \mathrm{L}, 0.707 \mathrm{mmol})$ was added in a single portion and the reaction mixture was heated to reflux and stirred for $48 \mathrm{~h}$. After cooling, ether $(60 \mathrm{~mL})$ was added, and the ethereal solution was washed with aqueous $\mathrm{NaOH}$ $\left(1 \mathrm{M} ; 3 \times 10 \mathrm{~mL}\right.$ ). The organic layer was dried over $\mathrm{MgSO}_{4}$ and concentrated under reduced pressure to give a solid. This was purified by flash column chromatography (8:2 light petroleum/ethyl acetate) to give the title compound as a colorless solid (125 mg, 75\%), mp 161-163 ${ }^{\circ} \mathrm{C}$. Found: $\left[\mathrm{M}+\mathrm{H}^{+}\right]$, 597.2287. $\mathrm{C}_{39} \mathrm{H}_{33} \mathrm{O}_{6}{ }^{+}$requires 597.2272; $\nu_{\max }\left(\mathrm{CHCl}_{3}\right) / \mathrm{cm}^{-1} 3305,3011,1645,1623,1605,1498$, $1443,1379,1270,1182,1119,1048,1028 ; \delta_{\mathrm{H}}\left(400 \mathrm{MHz} ; \mathrm{CDCl}_{3}\right) 8.28$ $(1 \mathrm{H}, \mathrm{s}), 7.65(2 \mathrm{H}, \mathrm{d}, J 7.3), 7.52(2 \mathrm{H}, \mathrm{d}, J 7.3), 7.46-7.34(11 \mathrm{H}, \mathrm{m}), 6.89$ $(1 \mathrm{H}, \mathrm{s}), 6.55(1 \mathrm{H}, \mathrm{d}, J 1.8), 6.49(1 \mathrm{H}, \mathrm{d}, J 1.8), 5.28(2 \mathrm{H}, \mathrm{s}), 5.20(2 \mathrm{H}, \mathrm{s})$, $5.13(2 \mathrm{H}, \mathrm{s}), 2.57(1 \mathrm{H}, \mathrm{s}), 1.72(6 \mathrm{H}, \mathrm{s}) ; \delta_{\mathrm{C}}\left(100 \mathrm{MHz} ; \mathrm{CDCl}_{3}\right) 174.5(\mathrm{C})$,
$163.2(\mathrm{C}), 160.7$ (C), 159.7 (C), $157.4(\mathrm{C}), 152.5(\mathrm{C}), 142.2(\mathrm{C}), 136.4(\mathrm{C})$, $136.9(\mathrm{C}), 135.7(\mathrm{C}), 128.8(\mathrm{CH}), 128.7(\mathrm{CH}), 128.6(\mathrm{CH}), 128.4(\mathrm{CH})$, 128.1 (CH), $127.7(\mathrm{CH}), 127.6(\mathrm{CH}), 127.2(\mathrm{CH}), 126.8(\mathrm{CH}), 119.9(\mathrm{CH})$, 116.4 (C), 107.6 (C), 100.7 (CH), $97.2(\mathrm{CH}), 94.1(\mathrm{CH}), 85.5(\mathrm{C}), 74.9(\mathrm{C})$, $74.3(\mathrm{CH}), 70.9\left(\mathrm{CH}_{2}\right), 70.8\left(\mathrm{CH}_{2}\right), 70.5\left(\mathrm{CH}_{2}\right), 29.6(\mathrm{Me})$.

\subsection{1. $5,9,11-T r i b e n z y l o x y-3,3-d i m e t h y l p y r a n o[3,2-a] x a n t h e n-$ 12(3H)-one 14}<smiles>CC1(C)C=Cc2c(c(OCc3ccccc3)cc3oc4cc(OCc5ccccc5)cc(OCc5ccccc5)c4c(=O)c23)O1</smiles>

A solution of 7-(2,2-dimethylbut-3-ynyl)-1,3,6-tribenzyloxy$9 H$-xanthen-9-one 13 (10 mg, $0.02 \mathrm{mmol})$ in toluene $(2 \mathrm{~mL})$ was heated under reflux for $2.5 \mathrm{~h}$. The solvent was evaporated and the residue purified by flash column chromatography (4:1 light petroleum/ethyl acetate) to give the title compound as a colorless solid (10 mg, 100\%), mp 174-175 ${ }^{\circ} \mathrm{C}$. Found: $\left[\mathrm{M}+\mathrm{H}^{+}\right]$, 597.2283. $\mathrm{C}_{39} \mathrm{H}_{33} \mathrm{O}_{6}{ }^{+}$requires 597.2272; $\nu_{\max }\left(\mathrm{CHCl}_{3}\right) / \mathrm{cm}^{-1} 3011,2928,1701$, $1615,1438,1378,1274,1192,1166,1125,1059,1016 ; \delta_{\mathrm{H}}(400 \mathrm{MHz}$; $\left.\mathrm{CDCl}_{3}\right) 8.14(1 \mathrm{H}, \mathrm{d}, J$ 9.8), $7.62(2 \mathrm{H}, \mathrm{d}, J$ 7.3 ), 7.49-7.35 (13H, m), 6.74 $(1 \mathrm{H}, \mathrm{s}), 6.48(1 \mathrm{H}, \mathrm{d}, J 2.1), 6.43(1 \mathrm{H}, \mathrm{d}, J 2.1), 5.85(1 \mathrm{H}, \mathrm{d}, J 9.8), 5.30$ $(4 \mathrm{H}, \mathrm{s}), 5.09(2 \mathrm{H}, \mathrm{s}), 1.53(6 \mathrm{H}, \mathrm{s}) ; \delta_{\mathrm{C}}\left(100 \mathrm{MHz} ; \mathrm{CDCl}_{3}\right) 176.9(\mathrm{C}), 162.9$ (C), 160.5 (C), 158.8 (C), 152.3 (C), 151.3 (C), 139.8 (C), 136.6 (C), 136.4 (C), $135.8(\mathrm{C}), 131.8(\mathrm{CH}), 128.8(\mathrm{CH}), 128.7(\mathrm{CH}), 128.6(\mathrm{CH}), 128.4$ $(\mathrm{CH}), 128.0(\mathrm{CH}), 127.6(\mathrm{CH} \times 2), 126.9(\mathrm{CH}), 126.7(\mathrm{CH}), 121.6(\mathrm{CH})$, $120.9(\mathrm{C}), 111.8(\mathrm{C}), 108.5(\mathrm{C}), 101.1(\mathrm{CH}), 97.3(\mathrm{CH}), 93.5(\mathrm{CH}), 75.3$ (C), $70.8\left(\mathrm{CH}_{2}\right), 70.7\left(\mathrm{CH}_{2}\right), 70.4\left(\mathrm{CH}_{2}\right), 27.1(\mathrm{Me})$.

\subsection{5,9,11-Trihydroxy-3,3-dimethylpyrano[3,2-a]xanthen- 12(3H)-one (toxyloxanthone B) 3a}

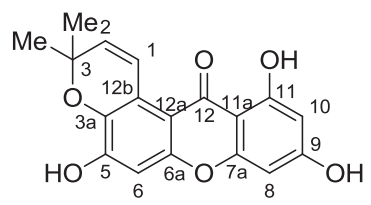

To a stirred solution of 5,9,11-tribenzyloxy-3,3-dimethylpyrano [3,2-a]xanthen-12(3H)-one 14 (2 $\mathrm{mg}, 0.005 \mathrm{mmol})$, and pentamethylbenzene $(7 \mathrm{mg}, 0.048 \mathrm{mmol})$ in dry dichloromethane $(1 \mathrm{~mL})$ at $-78{ }^{\circ} \mathrm{C}$ was added $\mathrm{BCl}_{3}$ (solution $1.0 \mathrm{M}$ in dichloromethane; $0.03 \mathrm{~mL}$ ) dropwise over $10 \mathrm{~min}$. After $30 \mathrm{~min}$ at $-78{ }^{\circ} \mathrm{C}$, the reaction mixture was warmed to room temperature and stirred for $16 \mathrm{~h}$. TLC and MS analysis showed the presence of the mono-benzylated compound, so extra $\mathrm{BCl}_{3}$ (solution $1.0 \mathrm{M}$ in dichloromethane; $0.03 \mathrm{~mL}$ ) was added and the reaction mixture was stirred for a further $1 \mathrm{~h}$, before being quenched with a mixture of chloroform and methanol (9:1, $2 \mathrm{~mL})$. The excess solvent was removed under reduced pressure. The residue was purified by flash chromatography ( $4: 1$ light petroleum/ethyl acetate) to give the title compound as a pale yellow solid ( $1 \mathrm{mg}, 64 \%$ ), mp 318-319 ${ }^{\circ} \mathrm{C}$ (lit., ${ }^{17} \mathrm{mp} \mathrm{304-306}{ }^{\circ} \mathrm{C}$ ). Found: $\left[\mathrm{M}+\mathrm{H}^{+}\right.$], 327.0864 . $\mathrm{C}_{18} \mathrm{H}_{15} \mathrm{O}_{6}{ }^{+}$requires 327.0863; $\nu_{\max }\left(\mathrm{CHCl}_{3}\right) / \mathrm{cm}^{-1} 3691,3607,1701$, $1602,1456,1249,1028,850 ; \delta_{\mathrm{H}}\left(500 \mathrm{MHz}\right.$; acetone- $\left.d_{6}\right) 13.38(1 \mathrm{H}, \mathrm{s}$, $11-\mathrm{OH}), 9.60$ (1H, br s, 5-OH), $9.18(1 \mathrm{H}, \mathrm{br} \mathrm{s}, 9-\mathrm{OH}), 8.03(1 \mathrm{H}, \mathrm{d}, \mathrm{J} 10.2$, $\mathrm{H}-1), 6.82(1 \mathrm{H}, \mathrm{s}, \mathrm{H}-6), 6.34(1 \mathrm{H}, \mathrm{d}, J 2.1, \mathrm{H}-8), 6.21$ (1H, d, J 2.1, H-10), $5.94(1 \mathrm{H}, \mathrm{d}, J 10.2, \mathrm{H}-2), 1.46(6 \mathrm{H}, \mathrm{s}, \mathrm{Me}-13) ; \delta_{\mathrm{C}}\left(125 \mathrm{MHz}\right.$; acetone- $\left.d_{6}\right)$ 180.5 (C=O), 165.3 (C-7a), 163.3 (C-11), 157.0 (C-9), 157.0 (C-6a), 155.6 (C-5), 141.3 (C-4a), 129.6 (CH-2), 122.2 (CH-1), 118.0 (C-12b), 103.2 (CH-6), 102.0 (C-11a), 101.6 (C-12a), 97.6 (CH-10), $93.0(\mathrm{CH}-8)$, 74.9 (C-3), 26.2 (Me-13). 
3.13. 5,9,11-Trimethoxy-3,3-dimethylpyrano[3,2-a]xanthen12(3H)-one (toxyloxanthone $B$ trimethyl ether) $3 \mathrm{~b}$

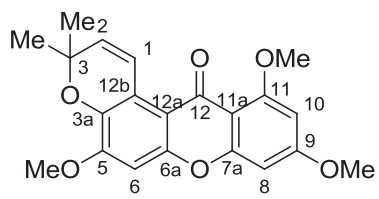

To a stirred solution of 5,9,11-trihydroxy-3,3-dimethylpyrano [3,2-a]xanthen-12(3H)-one 3a (2 mg, $0.006 \mathrm{mmol})$, and anhydrous potassium carbonate $(5 \mathrm{mg}, 0.037 \mathrm{mmol}$ ) in acetone $(1 \mathrm{~mL})$ was added dimethyl sulfate $(0.002 \mathrm{~mL})$ and the mixture was heated to reflux and stirred for $16 \mathrm{~h}$. The excess of solvents was removed under reduced pressure and the residue was purified by flash chromatography (4:1 light petroleum/ethyl acetate to 2:1 light petroleum/ethyl acetate) to give the title compound as a colorless solid ( $2 \mathrm{mg}, 89 \%$ ), mp $125-126{ }^{\circ} \mathrm{C}$ (lit., ${ }^{16} \mathrm{mp} 192-193{ }^{\circ} \mathrm{C}$ ). Found: $\left[\mathrm{M}+\mathrm{H}^{+}\right], 369.1343 . \mathrm{C}_{21} \mathrm{H}_{21} \mathrm{O}_{6}{ }^{+}$requires $369.1333 ; \nu_{\max }$ $\left(\mathrm{CHCl}_{3}\right) / \mathrm{cm}^{-1}$ 3156, 2903, 2254, 1795, 1618, 1467, 1383, 1097, 905, $650 ; \delta_{\mathrm{H}}\left(500 \mathrm{MHz}\right.$; acetone- $\left.d_{6}\right) 8.10(1 \mathrm{H}, \mathrm{d}, J 10.2, \mathrm{H}-1), 6.73(1 \mathrm{H}, \mathrm{s}$, $\mathrm{H}-6), 6.42$ (1H, d, J 2.3, H-8), 6.32 (1H, d, J 2.3, H-10), 5.77 (1H, d, J 10.2, H-2), 3.97 (3H, s, 11-OMe), 3.95 (3H, s, 5-OMe), 3.90 (3H, s, 9OMe), 1.48 (6H, s, 3-Me); $\delta_{\mathrm{C}}\left(125 \mathrm{MHz}\right.$; acetone- $\left.d_{6}\right) 177.2(\mathrm{C}), 164.1$ (C), 161.8 (C), 158.9 (C), $153.4(\mathrm{C}), 151.6$ (C), 139.2 (C), $131.6(\mathrm{CH})$, $121.5(\mathrm{CH}), 120.7(\mathrm{C}), 111.2(\mathrm{CH}), 107.9(\mathrm{C}), 98.7(\mathrm{C}), 95.0(\mathrm{CH}), 92.1$ (CH), $75.4(\mathrm{C}), 56.3$ (OMe), 56.2 (OMe), 55.6 (OMe), $27.1(\mathrm{Me})$.

\section{Acknowledgements}

We thank Professor G. Cirrincione (University of Palermo) for his interest, and the University of Palermo for support (to D.G.).

\section{Supplementary data}

Copies of NMR spectra. Supplementary data associated with this article can be found in the online version, at http://dx.doi.org/ 10.1016/j.tet.2013.12.055.

\section{References and notes}

1. Masters, K.-S.; Braese, S. Chem. Rev. 2012, 112, 3717-3776.

2. Jantan, I.; Saputri, F. C. Phytochemistry 2012, 80, 58-63.

3. Ryu, H. W.; Cho, J. K.; Curtis-Long, M. J.; Yuk, H. J.; Kim, Y. S.; Jung, S.; Kim, Y. S.; Lee, B. W.; Park, K. H. Phytochemistry 2011, 72, 2148-2154.

4. Xia, Z.-X.; Zhang, D.-D.; Liang, S.; Lao, Y.-Z.; Zhang, H.; Tan, H.-S.; Chen, S.-L.; Wang, X.-H.; Xu, H.-X. J. Nat. Prod. 2012, 75, 1459-1464.

5. Tantapakul, C.; Phakhodee, W.; Ritthiwigrom, T.; Cheenpracha, S.; Prawat, U.; Deachathai, S.; Laphookhieo, S. J. Nat. Prod. 2012, 75, 1660-1664.

6. Klaiklay, S.; Sukpondma, Y.; Rukachaisirikul, V.; Phongpaichit, S. Phytochemistry 2013, 85, 161-166.

7. Hamada, M.; Iikubo, K.; Ishikawa, Y.; Ikeda, A.; Umezawa, K.; Nishiyama, S. Bioorg. Med. Chem. Lett. 2003, 13, 3151-3153.

8. Iikubo, K.; Ishikawa, Y.; Ando, N.; Umezawa, K.; Nishiyama, S. Tetrahedron Lett. 2002, 43, 291-293.

9. Carpenter, I.; Locksley, H. D.; Scheinmann, F. Phytochemistry 1969, 8 , 2013-2025.

10. Ampofo, S. A.; Waterman, P. G. Phytochemistry 1986, 25, 2351-2355.

11. Ee, G. C. L.; Cheow, Y. L. Asian J. Chem. 2008, 20, 343-351.

12. Ha, L. D.; Hansen, P. E.; Vang, O.; Duus, F.; Pham, H. D.; Nguyen, L.-H. D. Chem. Pharm. Bull. 2009, 57, 830-834.

13. Deshpande, V. H.; Rama Rao, A. V.; Varadan, M.; Venkatar, K. Indian J. Chem. 1973, 11, 518-524.

14. Kirtany, J. K.: Paknikar, S. K. Indian J. Chem. 1975, 13, 104.

15. Cotterill, P. J.; Scheinmann, F. J. Chem. Soc., Chem. Commun. 1975, 664-665.

16. Cotterill, P. J.; Scheinmann, F. J. Chem. Soc., Perkin Trans. 1 1980, 2353-2357.

17. Ishiguro, K.; Fukumoto, H.; Nakajima, M.; Isoi, K. Phytochemistry 1993, 33, $839-840$.

18. Tanaka, N.; Takaishi, Y.; Shikishima, Y.; Nakanishi, Y.; Bastow, K.; Lee, K. H.; Honda, G.; Ito, M.; Takeda, Y.; Kodzhimatov, O. K.; Ashurmetov, O. J. Nat. Prod. 2004, 67, 1870-1875.

19. Zhao, J.; Larock, R. C. Org. Lett. 2005, 7, 4273-4275.

20. Zhao, J.; Larock, R. C. J. Org. Chem. 2007, 72, 583-588.

21. Gampe, C. M.; Carreira, E. M. Angew. Chem., Int. Ed. 2012, 51, 3766-3778.

22. Tadross, P. M.; Stoltz, B. M. Chem. Rev. 2012, 112, 3550-3577.

23. Dubrovskiy, A. V.; Markina, N. A.; Larock, R. C. Org. Biomol. Chem. 2013, 11, 191-218.

24. Tadross, P. M.; Gilmore, C. D.; Bugga, P.; Virgil, S. C.; Stoltz, B. M. Org. Lett. 2010, $12,1224-1227$.

25. Behrman, E. J. Org. React. 1988, 35, 421-511.

26. Bruder, M.; Smith, S. J.; Blake, A. J.; Moody, C. J. Org. Biomol. Chem. 2009, 7, 2127-2134.

27. Bieg, T.; Szeja, W. Synthesis 1985, 76-77.

28. Okano, K.; Okuyama, K.-i.; Fukuyama, T.; Tokuyama, H. Synlett 2008 1977-1980.

29. Tangdenpaisal, K.; Sualek, S.; Ruchirawat, S.; Ploypradith, P. Tetrahedron 2009, 65, 4316-4325. 